\title{
Aspects of reproductive biology of wild-caught polar cod (Boreogadus saida) from Svalbard waters
}

\author{
Jasmine Nahrgang ${ }^{1,2} \cdot$ Ekaterina Storhaug $^{1,3} \cdot$ Svetlana A. Murzina $^{4} \cdot$ \\ Olympe Delmas $^{1} \cdot$ Nina N. Nemova ${ }^{4} \cdot$ Jørgen Berge $^{1,2}$
}

Received: 26 February 2015/Revised: 11 November 2015/Accepted: 14 November 2015/Published online: 27 November 2015

(C) The Author(s) 2015. This article is published with open access at Springerlink.com

\begin{abstract}
Polar cod (Boreogadus saida) is considered a key species in the Arctic marine ecosystems. Yet detailed or even basic knowledge regarding its biology and adaptations, especially during the polar night, is in many cases poor. Data are presently unavailable in Western literature on the gonad development of polar cod and its reproductive biology in wild specimens. Accordingly, gonad development of wild-caught polar cod from fjords of the Svalbard archipelago was studied across seasons (April, August, September, November and January). Histological analyses of polar cod showed strong indication of a group-synchronous oocyte development with determinate fecundity and iteroparity. Females started gonadal development prior to April and had not yet reached the final stage of maturation in January. Testes matured more rapidly, with males ready to spawn in January. Furthermore, our data show that polar cod were able to reach sexual maturity at age $1+$. Based on our data and previous reports, we hypothesise that polar cod is a total spawner.
\end{abstract}

Jasmine Nahrgang and Ekaterina Storhaug have contributed equally to this work.

This article belongs to the special issue on the "Ecology of Arctic Gadids", coordinated by Franz Mueter, Jasmine Nahrgang, John Nelson and Jørgen Berge.

Jasmine Nahrgang

jasmine.m.nahrgang@uit.no

1 Department of Arctic and Marine Biology, UiT The Arctic University of Norway, 9037 Troms $\varnothing$, Norway

2 University Centre in Svalbard, 9171 Longyearbyen, Norway

3 Akvaplan-niva, Fram Centre, 9296 Troms $\varnothing$, Norway

4 Institute of Biology, Karelian Research Centre, RAS, Petrozavodsk, Russia
Keywords Boreogadus saida $\cdot$ Reproduction . Iteroparous · Life history strategies · Group-synchronous

\section{Introduction}

Polar cod (Boreogadus saida) is a circum-Arctic species common in both open and ice-covered waters of the Arctic shelf seas (Ponomarenko 1968; Rass 1968; Craig et al. 1982). It is considered to play a key role in the Arctic marine food web (Bradstreet et al. 1986; Jensen et al. 1991; Gjøsæter 2009), being an important link between the lower (e.g. zooplankton) and the higher trophic levels (seabirds and mammals) (Bradstreet and Cross 1982). However, gaps in knowledge remain concerning its reproductive biology, life cycle and adaptations to the Arctic environment. Polar cod has been reported to reproduce between November and March (reviewed by Hop and Gjøsæther 2013). A recent study by Nahrgang et al. (2014) indicated that polar cod is an iteroparous species, although males seem to become sexually mature at a younger age than females and also present a reduced life expectancy. Limited access to field data during the polar night, however, has hindered comprehensive and holistic studies of the reproductive biology and development of polar cod (see Berge et al. 2015 for a review). Rather, most of the existing knowledge on polar cod reproductive biology has been obtained from studies carried out on captive fish (Graham and Hop 1995; Sakurai et al. 1998) including experimental data on spawning energetics and fecundity estimates (Hop et al. 1995), egg characteristics (Andriyashev 1954; Graham and Hop 1995; Ponomarenko 2000) and optimal conditions for spawning (Altukhov 1979; Lapin and Matzuk 1981) and embryonic development (Doroshev and Aronovich 1974; Aronovich et al. 1975; Sakurai et al. (1998)). Hop et al. (1995) showed 
that polar cod invested high levels of energy in the reproduction and lost up to $50 \%$ of its total body mass during spawning, with liver and somatic tissues providing a substantial proportion of the total invested energy. Finally, oogenesis was first studied in polar cod by Christophorov (1978), who concluded that polar cod was a total spawner producing few but large eggs. To the best of our knowledge, developmental characteristics of male gonads in $B$. saida have not previously been reported in the scientific literature.

Here, we present the first comprehensive study on wildcaught polar cod aimed at histologically characterising gonad development of both female and male specimens during their reproductive season. The study was carried out in the high Arctic archipelago of Svalbard (Norway). We contrast our results with previously published data from captive fish and other geographical regions (eastern Barents Sea, e.g. Christophorov 1978) with the main aim of providing new insights into the reproductive strategies of polar cod. Although the present study includes samples from different locations, spatial variations are not discussed due to the low sample size for each location and the difficulty in dissociating seasonal trends from spatial variability.

\section{Materials and methods}

\section{Sampling}

Polar cod were collected by bottom trawling during cruises on RV Helmer Hanssen in Svalbard waters. Fish were sampled in November 2010, January 2011, 2012 and 2013, August 2011, September 2011 and April 2012 (Table 1, for geographical map see Fig. 1 in Nahrgang et al. 2014). Length (cm), total, somatic (without guts, liver and gonads), gonad and liver wet weights (g) were recorded as well as gender. Due to time constraints on board the ship, only a random subset of specimens was sampled for gonad histological analysis. Sections of gonad tissue were cut from the middle and posterior parts of the gonads of a subset of specimens and fixed in $4 \%$ formaldehyde for histological analysis. Otoliths were collected, and age was estimated (Gjøsæter and Ajiad 1994) using a Leica M205C microscope with a PlanApo $1.0 \times$ objective lens. For small transparent otoliths, white winter rings were counted on whole otoliths in sub-surface light; for all larger otoliths, cross sectioning and counting the rings under polarised light was necessary. Gonadosomatic index (GSI) and hepatosomatic index (HSI) were determined according to the equations:

GSI $=($ gonad wet weight $/$ somatic weight $) \times 100$

HSI $=($ liver wet weight $/$ somatic weight $) \times 100$.

\section{Histological analysis of gonads and terminology of maturation stages}

Gonads of female and male polar cod were analysed histologically to determine the maturation stages and seasonal development of oocytes and testes (Table 1). Standard histological methods of sample embedding into paraffin and staining with haematoxylin and eosin were applied (Mikodina et al. 2009). Gonad tissues were dehydrated through ascendant concentrations of ethanol (series 70, 80, 90, $96 \%$ and $2 \times 100 \%$ ), then cleaned in o-xylene and embedded in
Table 1 Overview of sampling time (month and year), location, sex ratio (F: female, $\mathrm{M}$ : male) and number of individuals considered for calculation of somatic indices (GSI, HSI) and histological analyses

\begin{tabular}{llllll}
\hline Month & Year & Location & Gender (F:M) & Somatic indices & Histology (F:M) \\
\hline August & 2011 & Billefjorden & $6: 4$ & 10 & $4: 2$ \\
September & 2011 & Billefjorden & $7: 8$ & 15 & $4: 7$ \\
& 2012 & Billefjorden & $6: 18$ & 24 & \\
& 2011 & Hinlopen & $10: 0$ & 10 & \\
& 2012 & Hinlopen & $24: 11$ & 35 & \\
November & 2012 & Kongsfjorden & $15: 9$ & 24 & $5: 8$ \\
January & 2012 & Rijpfjorden & $12: 13$ & 25 & \\
& 2011 & Isfjorden & $16: 19$ & 35 & \\
& 2011 & Adventfjorden & $8: 3$ & 11 & \\
& 2011 & Bellsund & $14: 9$ & 30 & \\
& 2012 & Rijpfjorden & $11: 8$ & 19 & \\
& 2013 & Rijpfjorden & $78: 64$ & 142 & $7: 0$ \\
\hline \multirow{4}{*}{ April } & 2013 & Kongsfjorden & $25: 11$ & 36 & 16 \\
\hline
\end{tabular}



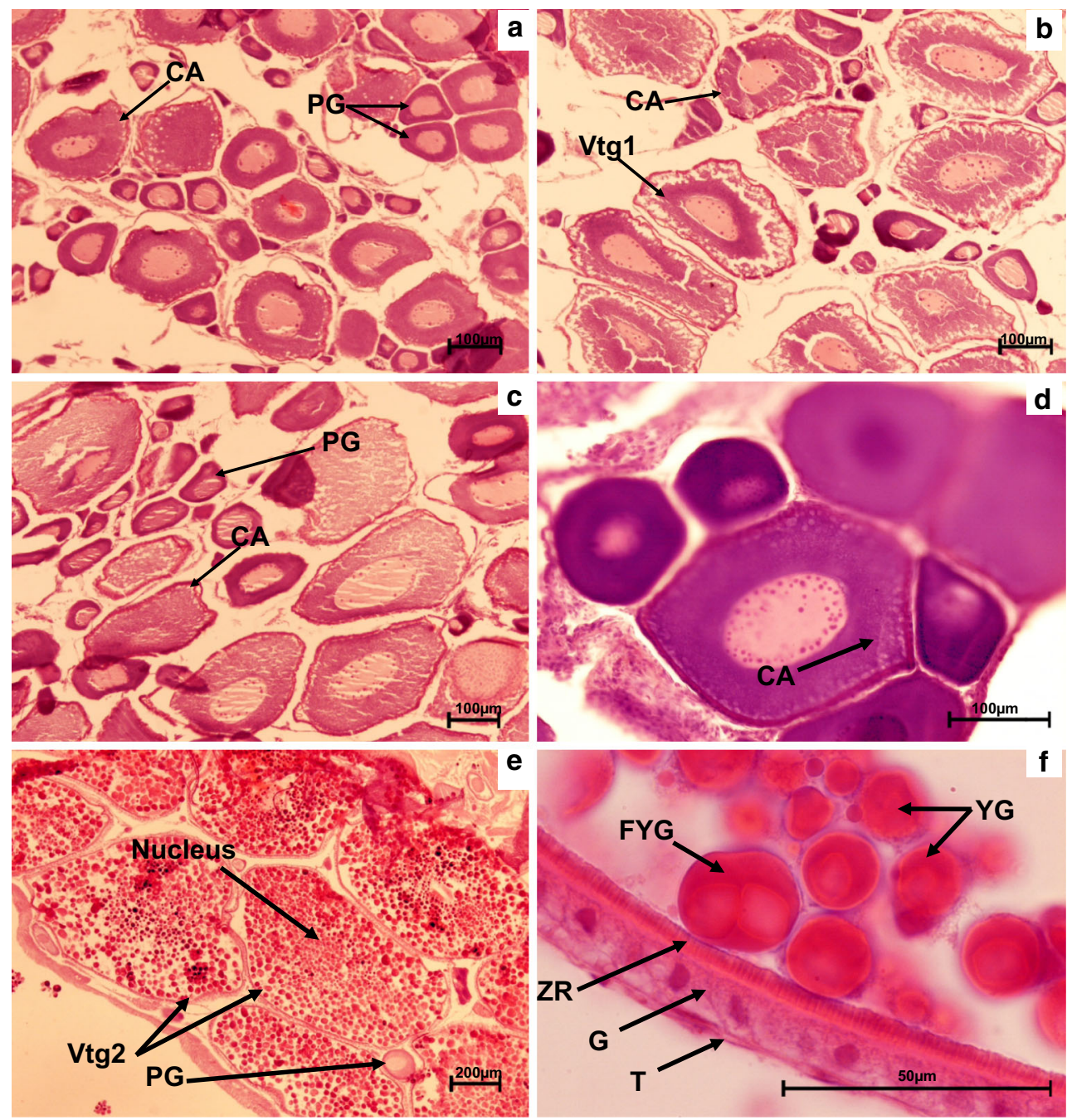

Fig. 1 Histological section of developing female gonads in April 2012 (a, b), September 2011 (c, d) and January 2011 (e, f). Oo oogonia, $P G$ primary growth oocytes, $C A$ cortical alveoli oocytes,

$V t g 2$ secondary vitellogenic oocytes, $Y G$ yolk globules, $F Y G$ fused yolk globules, $Z R$ zona radiata, $G$ zona granulosa, $T$ zona theca. Magnification $\times 100(\mathbf{a}-\mathbf{c}), \times 50(\mathbf{e}), \times 200(\mathbf{d}), \times 400(\mathbf{f})$

paraffin (Histomix, BioVitrum, Russia) using a MICROM spin tissue processor STP-120 (Thermo Fisher Scientific, USA). Paraffin moulds were prepared with a MICROM paraffin embedding centre EC-350 (Thermo Fisher Scientific, USA) and cut on a sliding microtome HM 450 (Thermo Fisher Scientific, USA) in transverse serial sections of thickness 7 and $9 \mu \mathrm{m}$. The slides were manually processed through the series of o-xylene and ethanol for paraffin elimination (dewaxing) and tissue dehydration and stained with haematoxylin (Mayer's haematoxylin) and eosin. Finally, the slides were mounted using synthetic Bio Mount BM500 (Bio Optika, Italy). Histological sections were studied using the light microscope Axioskop 40 (Carl Zeiss) with magnifications of $50 \times, 100 \times, 200 \times$ and $400 \times$. Sections were photographed with camera Pixera Pro 150ES. Developmental stages were analysed according to Kjesbu et al. (1990), McMillan (2007) and Brown-Peterson et al. (2011), and oocyte size was determined using the program Videotest. For females, the sections analysed were selected based on the highest number of oocytes with a visible nucleus. The area of the slide analysed was limited to the frame of the picture. Only oocytes with nucleus in the middle of the cell were measured for diameter. The following oocyte developmental stage classification was used: oogonia (Oo), chromatin-nucleolus stage oocyte, perinucleolar stage oocyte and previtellogenic oocytes as primary growth oocyte (PG), cortical alveoli stage oocyte (CA), primary vitellogenesis oocyte (small granules of yolk at the periphery, Vtg1), secondary vitellogenesis oocytes (larger yolk globules throughout the cytoplasm, Vtg2), tertiary vitellogenesis oocytes (yolk accumulation completed, Vtg3), post-ovulatory follicle (POF) and atretic oocytes. 
For each individual specimen, 100 oocytes were counted when possible. The mean $( \pm \mathrm{SE})$ frequency of occurrence for each oocyte stage was calculated based on " $n$ " females for each month and maturity stage ("mature/developing" or "immature or resting") and assumed that the gonadal tissues were homogenous (Table 2). The individuals analysed histologically were classified as either "mature/developing" or "immature or resting". The latter characterisation was based on the presence of only Oo and PG in the female gonads, with no possibility to differentiate with certainty whether the individuals were immature (never spawned) or resting (Brown-Peterson et al. 2011).

For the specimens with no histological data available (see Table 1), we defined as "unknown maturity status" those specimens with low GSI. In fact, low GSI in the present dataset may be due to immaturity, early stages of gonadal development, resting or skipped spawning (Rideout and Tomkiewicz 2011).

\section{Statistical analysis}

Statistical analyses were performed using SPSS (IBM) version 22.0. Assumptions of normality and homogeneity of data were checked using normal P-plot and Levene's test, respectively (Quinn and Keough 2002). When requirements for normality and homogeneity of variances were met, a one-way ANOVA was performed to test differences in GSI and total length between locations for a specific sampling month, followed by a Games and Howell post hoc test for unequal sample size. When these requirements were not met, robust tests of equality of means (Welch ANOVA) were used. Differences between developing specimens and those with an unknown status (low GSI and no histological data available) were determined using a Student's $T$ test. For all analyses, statistical significance was considered at $p \leq 0.05$.

\section{Results and discussion}

\section{Seasonality of developing specimens}

In the present study, polar cod may have started their gonad development prior to April and it was still not complete in January. Moreover, gender differences in relation to developmental timing were observed, similarly to previous reports for captive specimens (Christophorov 1978; Hop et al. 1995). In April, five of the seven analysed females were mature and developing with a dominance of primary growth oocytes (PG, $60 \pm 5 \%$ ), cortical alveoli (CA, $25 \pm 5 \%$ ) and primary vitellogenesis (Vtg1, $15 \pm 6 \%$ ) (Table 2; Fig. 1a, b). In August and September (Fig. 1c, d), the eight analysed female specimens were at a similar stage of oocyte development as the developing individuals sampled in April, with more than $30 \%$ of the oocytes being in the CA stage and $30 \%$ (August specimens) in the Vtg1 stage (yolk globules at the periphery and lipid inclusions) (Table 2). The oocytes at the CA stage $(202 \pm 6 \mu \mathrm{m})$ showed a significantly increased diameter compared to the PG oocytes $(79 \pm 4 \mu \mathrm{m})$ (Fig. 1c). The CA oocytes were located close to the membrane, and the zona radiata membrane

Table 2 Frequency of occurence (mean $\%$ of total oocyte counts \pm SE) of oocytes in polar cod females caught in April, August, September, November and January

\begin{tabular}{|c|c|c|c|c|c|c|c|c|c|c|c|}
\hline \multirow[t]{2}{*}{ Season } & \multirow{2}{*}{$\begin{array}{l}\text { Developmental } \\
\text { phase }\end{array}$} & \multirow[t]{2}{*}{$n$ Females } & \multirow[t]{2}{*}{$n$ Oocytes } & \multirow{2}{*}{$\begin{array}{l}\text { Age (min- } \\
\max )\end{array}$} & \multicolumn{6}{|c|}{ Oogenesis stages (\%) } & \multirow{2}{*}{$\begin{array}{l}\text { Atretic } \\
\text { oocytes }\end{array}$} \\
\hline & & & & & Oo & PG & $\mathrm{CA}$ & Vtg1 & $\operatorname{Vtg} 2$ & Vtg3 & \\
\hline August & $\begin{array}{l}\text { Mature/ } \\
\text { developing }\end{array}$ & 4 & 400 & $3-4$ & 0 & $50 \pm 10$ & $30 \pm 8$ & $20 \pm 7$ & 0 & 0 & 0 \\
\hline September & $\begin{array}{l}\text { Mature/ } \\
\text { developing }\end{array}$ & 4 & 400 & $2-4$ & $10 \pm 3$ & $40 \pm 9$ & $40 \pm 9$ & 0 & 0 & 0 & $3 \pm 1$ \\
\hline November & $\begin{array}{l}\text { Mature/ } \\
\text { developing }\end{array}$ & 5 & 224 & $1-3$ & $9 \pm 4$ & $66 \pm 5$ & 0 & 0 & $24 \pm 6$ & 0 & $1 \pm 1$ \\
\hline \multirow[t]{2}{*}{ January } & $\begin{array}{l}\text { Mature/ } \\
\text { developing }\end{array}$ & 5 & 254 & $1-2$ & $24 \pm 4$ & $50 \pm 4$ & 0 & 0 & $23 \pm 4$ & 0 & $2 \pm 2$ \\
\hline & Immature/resting & 5 & 450 & $2-3$ & $36 \pm 6$ & $64 \pm 6$ & 0 & 0 & 0 & 0 & 0 \\
\hline \multirow[t]{2}{*}{ April } & $\begin{array}{l}\text { Mature/ } \\
\text { developing }\end{array}$ & 5 & 270 & 2 & 0 & $60 \pm 6$ & $25 \pm 5$ & $15 \pm 6$ & 0 & 0 & 0 \\
\hline & Immature/resting & 2 & 310 & 2 & $30 \pm 5$ & $70 \pm 5$ & 0 & 0 & 0 & 0 & 0 \\
\hline
\end{tabular}

$O o$ oogonia and chromatin-nucleolus stage oocyte, $P G$ perinucleolar stage oocyte or previtellogenic oocytes, $C A$ cortical alveoli, $V t g 1$ primary vitellogenesis oocytes (small granules of yolk at the periphery), Vtg2 secondary vitellogenesis oocytes (larger yolk globules throughout the cytoplasm), $\operatorname{Vtg} 3$ tertiary vitellogenesis oocytes (yolk accumulation completed) and atretic oocytes 
was thin but well visible under the light microscope (Fig. 1d). The Vtg1 oocytes $(306 \pm 19 \mu \mathrm{m})$ were significantly larger than the oocytes at the CA developmental stage $(202 \pm 6 \mu \mathrm{m})$. Developing females in November and January showed similar structures with a dominant generation of PG oocytes (66 \pm 5 and $50 \pm 4 \%$, respectively), Vtg2 (secondary vitellogenesis) oocytes ( $24 \pm 6$ and $23 \pm 4 \%$, respectively) and oogonia ( $9 \pm 4$ and $24 \pm 4 \%$, respectively) (Table 2 ; Fig. 1e). The increase in the frequency of occurrence in Oo in January samples compared to previous months is not fully understood, but may reflect population differences between fjords (Nahrgang et al. 2014). Yolk globules were present in the cytoplasm of vitellogenic oocytes in November and some began to fuse in the January samples (Fig. 1f). The mean diameter of the vitellogenic oocytes increased significantly from November $(396 \pm 1 \mu \mathrm{m})$ to January $(606 \pm 17 \mu \mathrm{m})$. This increase in size was corroborated by a significant increase in GSI in January compared to the other sampling month (Table 3).

Based on the histological analyses performed on polar cod collected in Isfjorden in January 2011, the final maturation stages with migration of the nucleus to the animal pole and oocyte hydration had not started (Fig. 2). Polar cod eggs have a diameter between 1600 and $1800 \mu \mathrm{m}$ (Andriyashev 1954; Graham and Hop 1995; Hop et al.

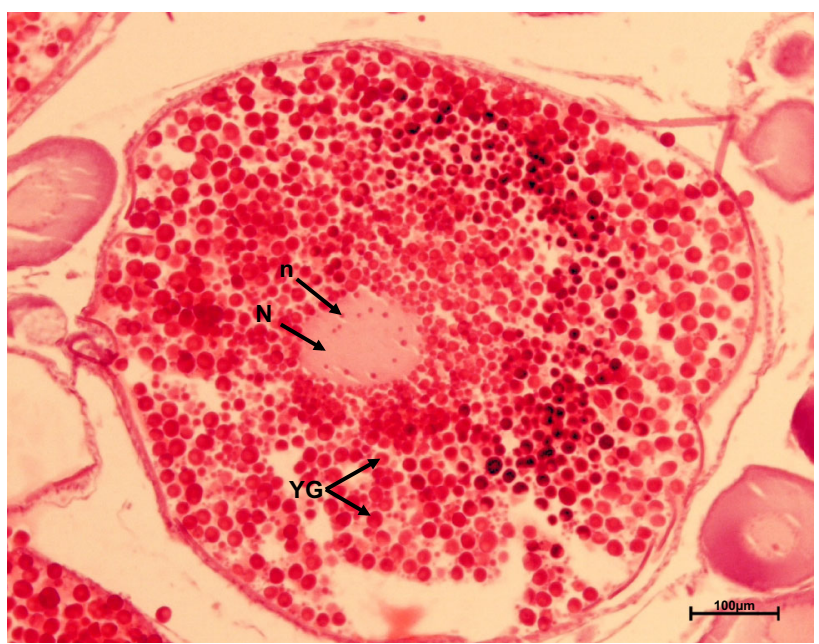

Fig. 2 Vitellogenic oocyte (Vtg2) of a developing female in January 2011. $N$ nucleus, $n$ nucleoli, $Y G$ yolk globules. Magnification $\times 100$

1995), and the most accepted time frame for spawning in the western Arctic is from late November to March (reviewed by Sameoto 1984; Hop and Gjøsæter 2013). Christophorov (1978) reported a quick final maturation stage of polar cod oocytes and the ovulation lasting between 6 and 8 days at sub-zero temperatures and spawning in January-February in the eastern Barents Sea.

Table 3 Gonadosomatic index (GSI, mean $\% \pm$ SE) of polar cod females and males categorised as unknown maturity status and mature/ developing

\begin{tabular}{|c|c|c|c|c|c|c|}
\hline \multirow[t]{2}{*}{ Month } & \multirow[t]{2}{*}{ Location } & \multirow[t]{2}{*}{ Year } & \multicolumn{2}{|l|}{ Female } & \multicolumn{2}{|l|}{ Male } \\
\hline & & & Unknown maturity status & Mature/developing & Unknown maturity status & Mature/developing \\
\hline August & Billefjorden & 2011 & $2.7 \pm 0.8(6)$ & & $3.1 \pm 1.0$ & \\
\hline \multirow[t]{6}{*}{ September } & Billefjorden & 2011 & $3.1 \pm 0.3^{\mathrm{a}, \mathrm{b}, \mathrm{c}}(7)$ & & $7.4 \pm 0.9^{\mathrm{a}}(8)$ & \\
\hline & Billefjorden & 2012 & $1.9 \pm 0.3^{\mathrm{a}}(6)$ & & $5.5 \pm 0.8^{\mathrm{a}}(18)$ & \\
\hline & Hinlopen & 2011 & $4.2 \pm 0.1^{\mathrm{d}}(10)$ & & & \\
\hline & Hinlopen & 2012 & $3.1 \pm 0.2^{\mathrm{c}, \mathrm{d}}(24)$ & & $6.6 \pm 0.8^{\mathrm{a}, \mathrm{b}}$ & \\
\hline & Kongsfjorden & 2012 & $2.4 \pm 0.1^{\mathrm{a}}(15)$ & & $3.9 \pm 0.5^{\mathrm{b}}(9)$ & \\
\hline & Rijpfjorden & 2012 & $3.1 \pm 0.2^{\mathrm{b}, \mathrm{c}}(12)$ & & $6.1 \pm 0.5^{\mathrm{a}}(13)$ & \\
\hline November & Isfjorden & 2010 & $4.0 \pm 0.6(16)$ & & $0.9 \pm 0.7$ & $31.2 \pm 1.4(16)$ \\
\hline \multirow[t]{7}{*}{ January } & Adventfjorden & 2011 & $1.0 \pm 0.1(7)$ & $16.4(1)$ & $0.1 \pm 0.0$ & \\
\hline & Isfjorden & 2011 & $1.1 \pm 0.1$ & $15.2 \pm 1.4^{\mathrm{a}, \mathrm{c}}(12)$ & $0.1(1)$ & $17.9 \pm 0.7^{\mathrm{a}}(13)$ \\
\hline & Bellsund & 2011 & $1.2 \pm 0.1(4)$ & $14.7 \pm 0.8^{\mathrm{a}}(10)$ & $0.3(1)$ & $21.4 \pm 1.5^{\mathrm{a}, \mathrm{b}}(8)$ \\
\hline & Rijpfjorden & 2012 & $1.4 \pm 0.1(6)$ & $21.3 \pm 1.1^{\mathrm{b}}(5)$ & $1.6 \pm 0.8$ & $27.1 \pm 5.6^{\mathrm{a}, \mathrm{b}}$ \\
\hline & Rijpfjorden & 2013 & $1.3 \pm 0.2(7)$ & $18.6 \pm 0.5^{\mathrm{b}, \mathrm{c}}(71)$ & & $24.8 \pm 0.9^{\mathrm{b}}(64)$ \\
\hline & Kongsfjorden & 2013 & $1.6 \pm 0.1(23)$ & $21.9 \pm 1.5^{\mathrm{a}, \mathrm{b}, \mathrm{c}}(2)$ & $0.7 \pm 0.3(5)$ & $23.2 \pm 2.3^{\mathrm{a}, \mathrm{b}}(6)$ \\
\hline & Krossfjorden & 2013 & $1.3 \pm 0.2(9)$ & $24.2 \pm 8.4^{\mathrm{a}, \mathrm{b}, \mathrm{c}}$ & $0.9 \pm 0.3(2)$ & $25.2 \pm 2.5^{\mathrm{a}, \mathrm{b}}(2)$ \\
\hline April & Adventfjorden & 2012 & $1.9 \pm 0.1(106)$ & & $1.1 \pm 0.1(42)$ & \\
\hline
\end{tabular}

It was not possible to differentiate between immature, resting or early developing gonads based on the GSI. Numbers in parentheses indicate number of specimens $(\mathrm{n})$. Letters indicate significant differences $(p<0.05)$ between locations for each specific month and maturity group 
The two distinctive oocyte generations (PG oocytes and Vtg2 oocytes) in November and January in developing specimens were indicative of a group-synchronous oocyte development (Murua and Saborido-Rey 2003), supporting earlier findings by Christophorov (1978). Previous reports (e.g. Hop et al. 1995 and Sakurai et al. 1998) and personal observation (Nahrgang, unpublished) of spawned specimens with totally empty gonads suggest that polar cod are total spawners with a group-synchronous development and determinate fecundity. Sakurai et al. (1998) also reported the spawning of most eggs during a single event at night. Finally, the presence of PG oocytes in all females throughout the reproductive cycle suggested an iteroparous strategy of polar cod females (Hop et al. 1995; LowerreBarbieri et al. 2011; Nahrgang et al. 2014), although no post-ovulatory follicles were found in any of our samples. Iteroparity was also supported by the presence of some residual oocytes in September specimens.

The spermatogenesis of polar cod followed the same stages of development as described for other teleost fishes (Ratty et al. 1990; Rideout and Burton 2000; Dziewulska and Domagala 2003; Fishelson et al. 2006; Bucholtz et al. 2008). All male gonads from April samples showed small gonads (Table 3). Unfortunately, we did not analyse male gonads from this time point and cannot determine whether these specimens were immature or resting. In late August/ early September, however, testes were in the developing phase for all analysed males, with the presence of spermatogonia, primary and secondary spermatocytes and partly spermatids (Fig. 3a, b). The testicular structure of polar cod collected in November showed a dominance of spermatids and the presence of spermatozoa (Fig. 3c, d). Furthermore, the sperm ducts were clearly visible, but spermatozoa were not present in the lumen of the lobule. At this stage, the GSI had increased significantly compared to September and April and remained significantly high in January (Table 3). Although the GSI of males $(31 \pm 1.4 \%)$ was significantly increased compared to that in females $(4.0 \pm 0.6 \%)$ in November, the males had not reached the spawning-capable phase characterised by the presence of spermatozoa in the lumen of the lobules (Brown-Peterson et al. 2011). The males reached this phase in January (Fig. 3e, f) and were thus ready for spawning earlier than female polar cod. This was also supported by stripping some male individuals during the January 2011 cruise and observing the immediate release of milt.

\section{Developing versus immature/resting specimens}

In November and January, polar cod males and females were divided into two distinctive groups based on a mean GSI above $15 \%$ and below $1.6 \%$, respectively (Table 3 ). This differentiation was not evident at any other sampling point. Histological analysis showed that the female specimens with low GSI were either immature or resting, presenting only oogonia $(36 \pm 1 \mu \mathrm{m})$ and $\mathrm{PG}$ oocytes $(107 \pm 2 \mu \mathrm{m})$ (Table 2; Fig. 4a, b). Immature $(n=1)$ and resting $(n=3)$ males in January were characterised by poorly developed testes (Brown-Peterson et al. 2011) (Fig. 4c, d).

Based on the GSI in January samples and histological analysis performed on a small set of individuals, the present study shows that the onset of sexual maturation could begin at the age of 1 year in both genders, as also previously reported by Moskalenko (1964). In opposition, a delayed maturation may also be possible with a 3-yearold female specimen that presented only Oo (33\%) and PG (67\%) (Table 2), although skipped spawning cannot be excluded. Similarly for males, some specimens older than 2 years showed low GSI in November $2010(n=1)$ and January $2013(n=4)$. The onset of maturity can be influenced by other factors than age, including energy status. For instance, previous work on Atlantic cod (Gadus morhua) hypothesised that immature specimens with lower total energy content than mature cod may not have the sufficient energy reserves to begin differentiation and growth of gonads (Eliassen and Vahl 1982). On the same data set as in the present study, Nahrgang et al. (2014) showed that the average length of developing specimens was generally larger than that of specimens with low GSI (assumed to be immature or resting) within each age class, implying an energy trade-off in the onset of sexual maturation in a given year (Table 4). By contrast, our HSI data did not show significant differences between developing specimens with high GSI and those with low GSI (Table 5). Previous reports on captive polar cod showed a total liver energy loss of approximately $80 \%$ during gonadal maturation (Hop et al. 1995). In the present study, HSI varied between 6 and $10 \%$ in AugustSeptember and 3-8 \% in January samples for both gender, with the exception of Hinlopen females (September 2011) that were significantly larger $(28.2 \pm 0.4 \mathrm{~cm})$ and showed an average HSI of $1.1 \pm 0.1 \%$. The strong drop in HSI close to spawning, seen in captive organisms by Hop et al. (1995), may be related to the significantly larger size of those specimens (15-28 cm compared to $11-20 \mathrm{~cm}$ in this study) and the size-dependent increase in GSI and thus the energy investment of larger, older individuals (Nahrgang et al. 2014).

\section{Conclusions and remaining gaps in knowledge}

The present study clearly indicates that polar cod females have a group-synchronous oocyte development. Furthermore, the study suggests that polar cod is an iteroparous total spawner with determinate fecundity, similarly to 


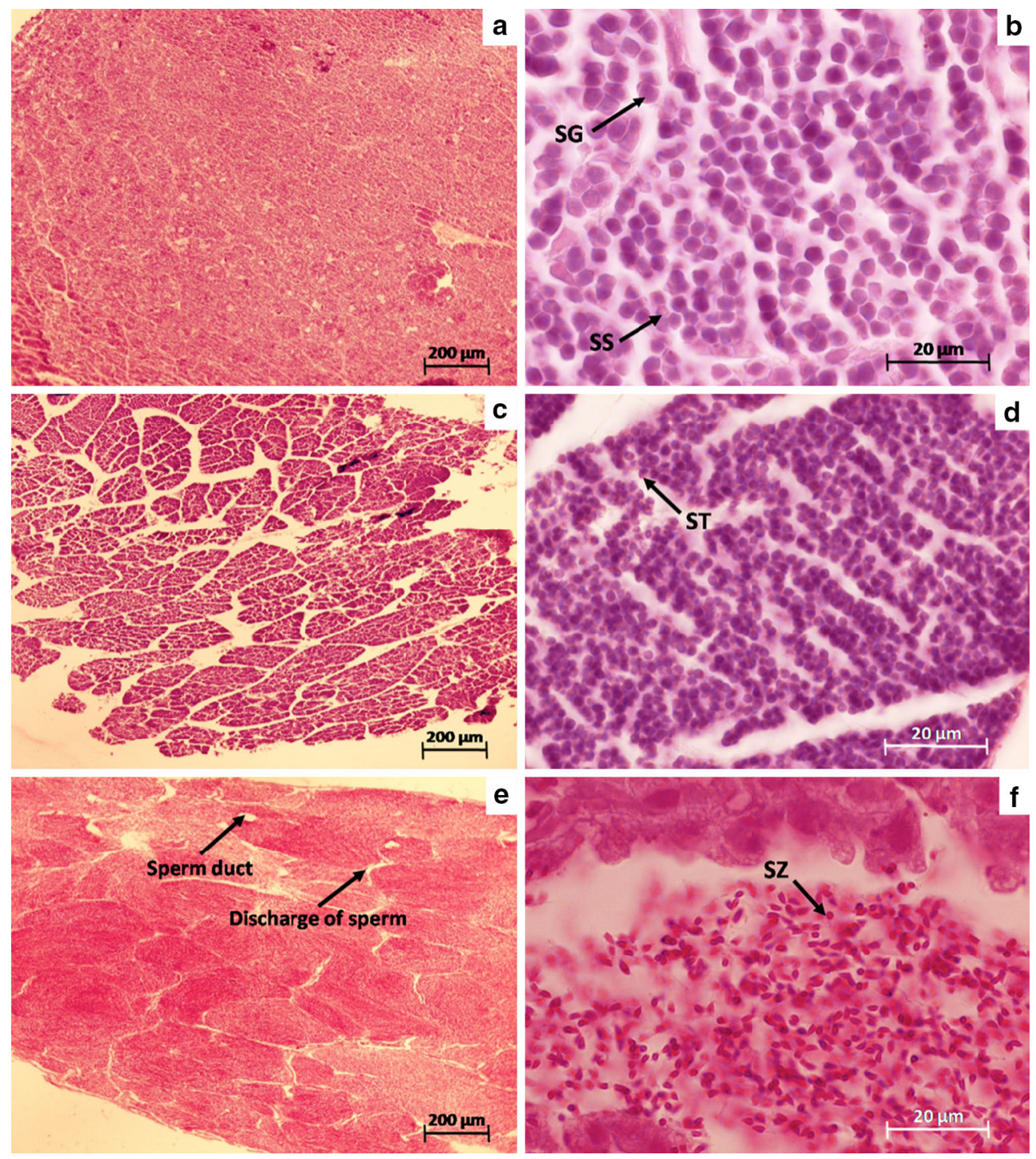

Fig. 3 Histological section of male gonads in September 2011 (a, b), November 2010 (c, d) and January 2011 (e, f). SG Spermatogonia, SS spermatocytes, $S T$ spermatids and $S Z$ spermatozoa. Magnification $\times 50(\mathbf{a}, \mathbf{c}, \mathbf{e}), \times 1000(\mathbf{b}, \mathbf{d}, \mathbf{f})$

herring (Clupea harengus) and redfishes (Murua and Saborido-Rey 2003). No direct observations have been made of spawning, although observations of large aggregations of polar cod in shallow areas in both the Russian (Ponomarenko 1968) and Canadian (Hop and Gjøsæter 2013) Arctic would support the claim made herein that polar cod is a total spawner. The presence of large and homogenous cohorts (Bouchard and Fortier 2011) also is indicative of such mass spawning, as is the synchronised development of gonads reported herein. These are important issues to consider in a rapidly changing Arctic (Wang and Overland 2009), as it follows from life history theory that a species characterised by a coordinated mass spawning, producing offspring with a narrow span of birth dates, demonstrates larger recruitment variability and potentially also suffers more severely from episodic environmental change (e.g. Lowerre-Barbieri et al. 2011). The breeding strategy of polar cod is yet to be understood. We, however, hypothesise based on current status of knowledge that polar cod is a capital breeder, as seen for other species with similar reproductive strategies (McBride et al. 2013). Important gaps in knowledge remain concerning pan-Arctic spatial variations in spawning patterns, timing and potential effects of warming climate on life history traits of polar cod (Bouchard et al. 2014; Nahrgang et al. 2014). Finally, differences in the characteristics of gonadal development may exist between populations inhabiting fjords of Svalbard influenced by different water masses and deserve more attention. 


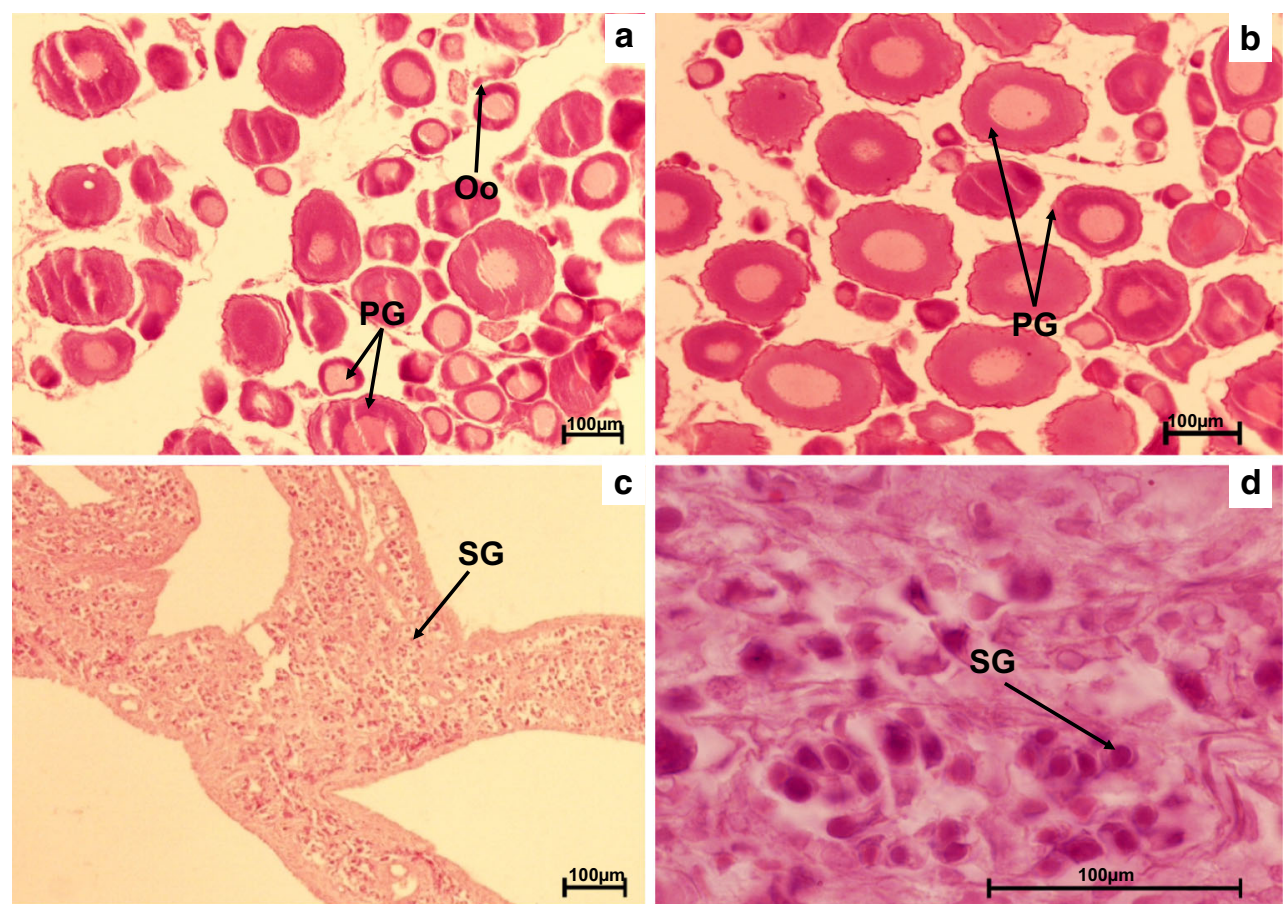

Fig. 4 Histological section of gonads from immature female in April 2012 (a) and January 2011 (b) and male in January 2011 (e, d). Oo oogonia, $P G$ primary growth oocytes, $S G$ Spermatogonia. Magnification $\times 100(\mathbf{a}-\mathbf{c}), \times 400(\mathbf{d})$

Table 4 Total length $(\mathrm{cm}$, mean $\pm \mathrm{SE}$ ) of polar cod females and males categorised as unknown maturity status and mature/developing

\begin{tabular}{|c|c|c|c|c|c|c|}
\hline \multirow[t]{2}{*}{ Month } & \multirow[t]{2}{*}{ Location } & \multirow[t]{2}{*}{ Year } & \multicolumn{2}{|l|}{ Female } & \multicolumn{2}{|l|}{ Male } \\
\hline & & & Unknown maturity status & Mature/developing & Unknown maturity status & Mature/developing \\
\hline August & Billefjorden & 2011 & $15.0 \pm 2.1(6)$ & & $13.3 \pm 1.6(4)$ & \\
\hline \multirow[t]{6}{*}{ September } & Billefjorden & 2011 & $15.8 \pm 0.8^{\mathrm{c}}(7)$ & & $14.8 \pm 0.9^{\mathrm{a}, \mathrm{b}}(8)$ & \\
\hline & Billefjorden & 2012 & $11.4 \pm 0.6^{\mathrm{d}}(6)$ & & $12.4 \pm 0.7^{\mathrm{a}}(18)$ & \\
\hline & Hinlopen & 2011 & $28.2 \pm 0.4^{\mathrm{a}}(10)$ & & & \\
\hline & Hinlopen & 2012 & $20.4 \pm 0.6^{\mathrm{b}}(24)$ & & $19.5 \pm 0.6^{\mathrm{c}, \mathrm{d}}(11)$ & \\
\hline & Kongsfjorden & 2012 & $15.4 \pm 0.6^{\mathrm{a}}(15)$ & & $14.0 \pm 0.8^{\mathrm{a}}(9)$ & \\
\hline & Rijpfjorden & 2012 & $16.3 \pm 1.2^{\mathrm{b}, \mathrm{c}}(12)$ & & $17.2 \pm 0.6^{\mathrm{b}, \mathrm{d}}(13)$ & \\
\hline November & Isfjorden & 2010 & $13.2 \pm 0.2(16)$ & & $14.9 \pm 1.9(3)$ & $13.7 \pm 0.4(16)$ \\
\hline \multirow[t]{7}{*}{ January } & Adventfjorden & 2011 & $12.8 \pm 0.3^{\mathrm{a}}(7)$ & $14.1(1)$ & $12.0 \pm 0.4(3)$ & \\
\hline & Isfjorden & 2011 & $12.9 \pm 0.8^{\mathrm{a}, \mathrm{b}}(4)$ & $12.8 \pm 0.3^{\mathrm{a}}(12)$ & $11.5(1)$ & $12.5 \pm 0.2^{\mathrm{a}}(13)$ \\
\hline & Bellsund & 2011 & $12.1 \pm 0.7^{\mathrm{a}, \mathrm{b}}$ & $12.7 \pm 0.3^{\mathrm{a}}(10)$ & $13.1(1)$ & $13.3 \pm 0.3^{\mathrm{a}}(8)$ \\
\hline & Rijpfjorden & 2012 & $13.9 \pm 0.5^{\mathrm{a}}(6)$ & $18.6 \pm 0.3^{\mathrm{b}}(5)$ & $13.4 \pm 0.6(4)$ & $18.8 \pm 1.6^{\mathrm{a}, \mathrm{c}}(4)$ \\
\hline & Rijpfjorden & 2013 & $12.9 \pm 0.4^{\mathrm{a}}(7)$ & $15.8 \pm 0.2^{\mathrm{c}}(71)$ & & $15.1 \pm 0.3^{\mathrm{c}}(64)$ \\
\hline & Kongsfjorden & 2013 & $10.6 \pm 0.5^{\mathrm{b}}(23)$ & $16.1 \pm 1.5^{\mathrm{a}, \mathrm{b}, \mathrm{c}}(2)$ & $12.1 \pm 1.4(5)$ & $14.5 \pm 0.8^{\mathrm{a}, \mathrm{c}}(6)$ \\
\hline & Krossfjorden & 2013 & $11.8 \pm 1.3^{\mathrm{a}, \mathrm{b}}(9)$ & $20.1 \pm 3.6^{\mathrm{a}, \mathrm{b}, \mathrm{c}}(3)$ & $12.5 \pm 2.6(2)$ & $17.6 \pm 2.7^{\mathrm{a}, \mathrm{c}}(2)$ \\
\hline April & Adventfjorden & 2012 & $13.1 \pm 0.2(106)$ & & $12.9 \pm 0.4(42)$ & \\
\hline
\end{tabular}

It was not possible to differentiate between immature, resting or early developing gonads based on the GSI. Numbers in parentheses indicate number of specimens $(\mathrm{n})$. Letters indicate significant differences $(p<0.05)$ between locations for each specific month and maturity group 
Table 5 Hepatosomatic index (HSI, mean $\% \pm \mathrm{SE}$ ) of polar cod females and males categorised as unknown maturity status and mature/ developing

\begin{tabular}{|c|c|c|c|c|c|c|}
\hline \multirow[t]{2}{*}{ Month } & \multirow[t]{2}{*}{ Location } & \multirow[t]{2}{*}{ Year } & \multicolumn{2}{|l|}{ Female } & \multicolumn{2}{|l|}{ Male } \\
\hline & & & Unknown maturity status & Mature/developing & Unknown maturity status & Mature/developing \\
\hline August & Billefjorden & 2011 & $7.8 \pm 1.4(6)$ & & $8.1 \pm 1.7$ & \\
\hline \multirow[t]{6}{*}{ September } & Billefjorden & 2011 & $6.0 \pm 0.7^{\mathrm{a}}(7)$ & & $5.9 \pm 0.8^{\mathrm{a}}(8)$ & \\
\hline & Billefjorden & 2012 & $7.4 \pm 1.0^{\mathrm{a}, \mathrm{c}}(6)$ & & $9.9 \pm 0.5^{\mathrm{b}}(18)$ & \\
\hline & Hinlopen & 2011 & $1.1 \pm 0.1^{\mathrm{b}}(10)$ & & & \\
\hline & Hinlopen & 2012 & $10.2 \pm 0.4^{\mathrm{c}}(24)$ & & $10.0 \pm 0.5^{\mathrm{b}}(11)$ & \\
\hline & Kongsfjorden & 2012 & $6.1 \pm 0.4^{\mathrm{a}}(15)$ & & $8.1 \pm 1.0^{\mathrm{a}, \mathrm{b}}(9)$ & \\
\hline & Rijpfjorden & 2012 & $9.7 \pm 0.5^{\mathrm{c}}(12)$ & & $10.3 \pm 0.6^{\mathrm{b}}(13)$ & \\
\hline November & Isfjorden & 2010 & $8.3 \pm 0.8(16)$ & & $7.5 \pm 0.6(3)$ & $8.4 \pm 0.5(16)$ \\
\hline \multirow[t]{7}{*}{ January } & Adventfjorden & 2011 & $6.1 \pm 0.6(7)$ & $7.0(1)$ & $6.1 \pm 1.2(3)$ & \\
\hline & Isfjorden & 2011 & $6.7 \pm 1.5$ & $8.4 \pm 0.8^{\mathrm{a}}(12)$ & $7.0(1)$ & $4.7 \pm 0.3(13)$ \\
\hline & Bellsund & 2011 & $5.3 \pm 0.6$ & $8.1 \pm 0.6^{\mathrm{a}}(10)$ & $5.7(1)$ & $3.5 \pm 0.5(8)$ \\
\hline & Rijpfjorden & 2012 & $5.5 \pm 0.9(6)$ & $7.3 \pm 1.1^{\text {a.b }}(5)$ & $6.8 \pm 0.5(4)$ & $5.0 \pm 0.9(4)$ \\
\hline & Rijpfjorden & 2013 & $6.9 \pm 1.4(7)$ & $5.8 \pm 0.3^{\mathrm{b}}(71)$ & & $4.1 \pm 0.3(64)$ \\
\hline & Kongsfjorden & 2013 & $4.9 \pm 0.5(23)$ & $6.0 \pm 1.6^{\mathrm{a} . \mathrm{b}}(2)$ & $7.4 \pm 1.9(5)$ & $6.1 \pm 1.1(6)$ \\
\hline & Krossfjorden & 2013 & $4.9 \pm 0.7(9)$ & $6.1 \pm 2.2^{\mathrm{a} . \mathrm{b}}$ & $6.6 \pm 1.9(2)$ & $3.9 \pm 0.7(2)$ \\
\hline April & Adventfjorden & 2012 & $4.9 \pm 0.1(106)$ & & $5.3 \pm 0.2(42)$ & \\
\hline
\end{tabular}

It was not possible to differentiate between immature, resting or early developing gonads based on the GSI. Numbers in parentheses indicate number of specimens $(\mathrm{n})$. Letters indicate significant differences $(p<0.05)$ between locations for each specific month and maturity group

Acknowledgments We thank the crew of RV Helmer Hanssen, the University Centre in Svalbard and the TUNU-Programme (UiTArctic University of Norway, Troms $\varnothing$ ) for providing ship time and polar cod samples. The project was financially supported by Akvaplan-niva AS (Troms $\varnothing$ ), the Norwegian Research Council through the Environmental Waste Management (EWMA) (nr 195160) and Polarisation (nr 214184) projects, the Arctic Field Grant (Svalbard Science Forum) and the Presidium of RAS "Searching fundamental research for development of the Russian Arctic" (nr 11406194001, 2014-2016).

\section{Compliance with ethical standards}

Conflict of interest The authors declare that they have no conflict of interest.

Human and animal rights All applicable international, national and/or institutional guidelines for the care and use of animals were followed. All procedures performed were in accordance with the ethical standards of the Norwegian animal welfare authorities.

Informed consent Informed consent was obtained from all individual participants included in the study.

Open Access This article is distributed under the terms of the Creative Commons Attribution 4.0 International License (http://crea tivecommons.org/licenses/by/4.0/), which permits unrestricted use, distribution, and reproduction in any medium, provided you give appropriate credit to the original author(s) and the source, provide a link to the Creative Commons license, and indicate if changes were made.

\section{References}

Altukhov KA (1979) About reproduction and development of polar cod Boreogadus saida (Lepechin) in the White Sea. Icthyology 19:874-882 (in Russian)

Andriyashev AP (1954) Fishes of the northern seas of the USSR. AN SSSR, Moscow, Leningrad, p 566 (in Russian)

Aronovich TM, Doroshev SI, Spectorova LV, Makhotin VM (1975) Egg incubation and larval rearing of navaga (Eleginus navaga Pall.), polar cod (Boreogadus saida Lepechin) and arctic flounder (Liopsetta glacialis Pall.) in the laboratory. Aquaculture 6:233-242

Berge J, Cottier F, Darnis G, Falk-Petersen S, Gabrielsen T et al (2015) In the dark: paradigms of Arctic ecosystems during polar night challenged by new understanding. Progr Oceanogr. doi:10. 1016/j.pocean.2015.08.005

Bouchard C, Fortier L (2011) Circum-arctic comparison of the hatching season of polar cod Boreogadus saida: a test of the freshwater winter refuge hypothesis. Progr Oceanogr 90:105-116

Bouchard C, Mollard S, Suzuki K, Robert D, Fortier L (2014) Contrasting the early life histories of sympatric Arctic gadids Boreogadus saida and Arctogadus glacialis in the Canadian Beaufort Sea. Polar Biol. doi:10.1007/s00300-014-1617-4

Bradstreet MSW, Cross WE (1982) Trophic relationships at High Arctic ice edges. Arctic 35:1-12

Bradstreet MSW, Finley KJ, Sekerak AD, Griffiths WB, Evans CR, Fabigan MF, Stallard HE (1986) Aspects of the biology of Arctic cod (Boreogadus saida) and its importance in Arctic marine food chains. Can Tech Rep Fish Aquat Sci 1491:viii + 193p

Brown-Peterson NJ, Wyanski DM, Saborido-Rey F, Macewicz BJ, Lowerre-Barbieri SK (2011) A standardized terminology for 
describing reproductive development in fishes. Mar Coast Fish 3:52-70

Bucholtz RH, Tomkiewicz J, Dalskov J (2008) Manual to determine gonadal maturity of herring (Clupea harengus L.) DTU Aquareport 197-08. National Institute of Aquatic Resources, Charlottenlund

Christophorov OL (1978) Gametogenesis and reproduction cycle of polar cod Boreogadus saida (Lepechin) in the Barents Sea. VNIRO Proc 130:33-46

Craig PC, Griffiths WB, Haldorson L, McElderry H (1982) Ecological studies of Arctic cod (Boreogadus saida) in Beaufort Sea coastal waters, Alaska. Can J Fish Aquat Sci 39:395-406

Doroshev SI, Aronovich TM (1974) The effects of salinity on embryonic and larval development of Eleginus navaga (Pallas), Boreogadus saida (Lepechin) and Liopsetta glacialis (Pallas). Aquaculture 4:353-362

Dziewulska K, Domagala J (2003) Histology of salmonid testes during maturation. Reprod Biol 3:47-61

Eliassen JE, Vahl O (1982) Seasonal variations in biochemical composition and energy content of liver, gonad and muscle of mature and immature cod, Gadus morhua (L.) from Balsfjorden, northern Norway. J Fish Biol 20:707-716

Fishelson L, Delarea Y, Gon O (2006) Testis structure, spermatogenesis, spermatocytogenesis, and sperm structure in cardinal fish (Apogonidae, Perciformes). Anat Embryol 211:31-46

Gjøsæter H (2009) Commercial fisheries (fish, seafood and marine mammals). In: Sakshaug E, Johnsen G, Kovacs K (eds) Ecosystem Barents Sea. Tapir Academic Publishers, Trondheim, pp 373-413

Gjøsæter H, Ajiad AM (1994) Growth of polar cod (Boreogadus saida, Lepechin) in the Barents Sea. ICES J Mar Sci 51:115-120

Graham M, Hop H (1995) Aspects of reproduction and larval biology of Arctic cod (Boreogadus saida). Arctic 48:130-135

Hop H, Gjøsæter H (2013) Polar cod (Boreogadus saida) and capelin (Mallotus villosus) as key species in marine food webs of the Arctic and the Barents Sea. Mar Biol Res 9:878-894

Hop H, Graham M, Trudeau VL (1995) Spawning energetics of Arctic cod (Boreogadus saida) in relation to seasonal development of the ovary and plasma sex steroid levels. Can J Fish Aquat Sci 52:541-550

Jensen T, Ugland KI, Anstensrud M (1991) Aspects of growth in Arctic cod, Boreogadus saida (Lepechin 1773). Polar Res $10: 547-552$

Kjesbu OS, Witthames PR, Solemdal P, Greer Walker M (1990) Ovulatory rhythm and a method to determine the stage of spawning in Atlantic cod (Gadus morhua). Can J Fish Aquat Sci 47:1185-1193

Lapin VI, Matzuk VE (1981) Dynamic of total chemical content of developing pelagic eggs of polar cod Boreogadus saida (Lepechin) and Atlantic cod Gadus morhua marin albi (Derjugin) in the White Sea. Icthyology 21:482-488
Lowerre-Barbieri SK, Ganias K, Saborido-Rey F, Murua H, Hunter JR (2011) Reproductive timing in marine fishes: variability, temporal scales, and methods. Mar Coast Fish 3:71-91

McBride RS, Somarakis S, Fitzhugh GR, Albert A, Yaragina NA et al (2013) Energy acquisition and allocation to egg production in relation to fish reproductive strategies. Fish Fish. doi:10.1111/ faf. 12043

McMillan DB (2007) Fish histology female reproductive systems. Springer, Dordrecht

Mikodina EV, Sedova MA, Chmilevskii DA, Mikulin AE, Pyanova SV, Poluektova OG (2009) Histology for ichthyologists: experience and advice. VNIRO, Moscow (in Russian)

Moskalenko BK (1964) Biology of the Arctic Cod (Boreogadus saida, Lepechin, 1774). Vopr Ikhtiol 4:433-443 (in Russian)

Murua H, Saborido-Rey F (2003) Female reproductive strategies of marine fish species of the North Atlantic. J Northw Atl Fish Sci 33:23-31

Nahrgang J, Varpe $\varnothing$, Korshunova E, Murzina S, Hallanger IG et al (2014) Gender specific reproductive strategies of an arctic key species (Boreogadus saida) and implications of climate change. PLoS One 9:e98452. doi:10.1371/journal.pone.0098452.s008

Ponomarenko VP (1968) Some data on the distribution and migrations of polar cod in the seas of the Soviet Arctic. Rapp P-V Réun Cons Perm Int Explor Mer 158:131-135

Ponomarenko VP (2000) Eggs, larvae, and juveniles of polar cod Boreogadus saida in the Barents, Kara, and White Seas. J Ichthyol 40:165-173

Quinn GP, Keough MJ (2002) Experimental design and data analysis for biologists. Cambridge University Press, Cambridge

Rass TS (1968) Spawning and development of polar cod. Rapp P-V Réun Cons Perm Int Explor Mer 158:135-137

Ratty FJ, Laurs RM, Kelly RM (1990) Gonad morphology, histology, and spermatogenesis in south Pacific albacore tuna Thunnus alalunga (Scombridae). Fish Bull 88:207-216

Rideout RM, Burton MPM (2000) The reproductive cycle of male Atlantic cod (Gadus morhua L.) from Placentia Bay, Newfoundland. Can J Zool 78:1017-1025

Rideout RM, Tomkiewicz J (2011) Skipped spawning in fishes: more common than you might think. Mar Coast Fish 3:176-189

Sakurai Y, Ishii K, Nakatani T, Yamaguchi H, Anma G, Jin M (1998) Reproductive characteristics and effects of temperature and salinity on the development and survival of eggs and larvae of Arctic cod (Boreogadus saida). Mem Fac Fish Hokkaido Univ 44:77-89

Sameoto DD (1984) Review of current information on Arctic cod (Boreogadus saida Lepechin) and bibliography. Bedford Institute of Oceanography, Dartmouth

Wang M, Overland JE (2009) A sea ice free summer Arctic within 30 years? Geophys Res Lett 36:L07502. doi:10.1029/ 2009GL037820 